\title{
Clear stent imaging for guiding complex coronary interventions
}

\section{Krešimir Gabaldo*, Đeiti Prvulović, Božo Vujeva, Irzal Hadžibegović, Ognjen Čančarević}

General Hospital "Dr. Josip Benčević", Slavonski Brod, Croatia
RECEIVED:

February 9, 2016

ACCEPTED:

February 20, 2016

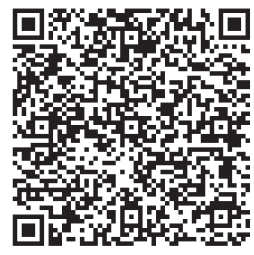

KEYWORDS: intravascular ultrasound, stent boost, complex lesions. CITATION: Cardiol Croat. 2016;11(3-4):117. | DOI: http://dx.doi.org/10.15836/ccar2016.117

*ADDRESS FOR CORRESPONDENCE: Krešimir Gabaldo, Opća bolnica "Dr. Josip Benčević", Andrije Štampara 42, HR-35000 Slavonski Brod, Croatia. / Phone: +385-98-139-8810 / E-mail: kresimir.gabaldo@sb.t-com.hr

ORCID: Krešimir Gabaldo, http://orcid.org/0000-0002-0116-5929 • Đeiti Prvulović, http://orcid.org/0000-0002-8041-1197 Božo Vujeva, http://orcid.org/0000-0003-0490-3832 • Irzal Hadžibegović, http://orcid.org/0000-0002-3768-9134 Ognjen Čančarević, http://orcid.org/0000-0002-1285-8042

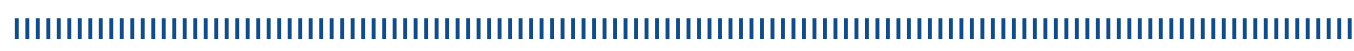

Complex lesions interventions are technically demanding and associated with higher rates of adverse events. In left main stenting, ostial lesions and bifurcation procedures, precise stent position, complete lesion coverage and full stent deployment (apposition) are mandatory. These procedures should be guided with other imaging modalities. Intravascular ultrasound (IVUS) is a gold standard for all these indications, but it is expensive, time consuming and carries some added per procedural risk. Clear stent imaging or stent boost is an enhancement of the radiological edge of the stent by digital management of regular X-ray images. It is a simple and fast method especially useful for proper stent positioning, control of stent deployment and apposition. During bifurcation stenting it also allows correct balloon positioning for proximal optimizing technique and correct positioning of side branch stenting in T-stenting and small protrusion technique. Recent studies investigated the accuracy of stent positioning and deployment guided with CLEARstent, compared it and also controlled it with IVUS. The results show sufficient specificity for conventional use in every day practice. ${ }^{1,2}$

We routinely started to use CLEARstent imaging in December 2015. The procedures were carried out on a Siemens Artis zee floor-mounted angiography system integrated with CLEARstent software.

We present some clinical cases where we were guided with CLEARstent imaging which definitely improved success of our procedures. The method is simple and quick, and as a center without IVUS, we now routinely use it in every complex lesion intervention.

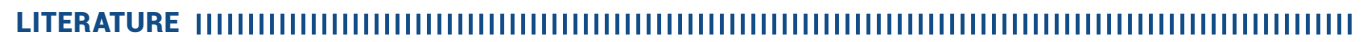

1. Tanaka N, Pijls NH, Koolen JJ, Botman KJ, Michels HR, Brueren BR, et al. Assessment of optimum stent deployment by stent boost imaging: comparison with intravascular ultrasound. Heart Vessels. 2013;28(1):1-6. Dol: http://dx.doi.org/10.1007/s00380-011-0202-9

2. Davies AG, Conway D, Reid S, Cowen AR, Sivananthan M. Assessment of coronary stent deployment using computer enhanced $x$-ray imagesvalidation against intravascular ultrasound and best practice recommendations. Catheter Cardiovasc Interv. 2013;81(3):419-27. DOI: http://dx.doi.org/10.1002/ccd.23366 